\title{
Thiosemicarbazones of 2-acetylpyridine, 2-acetylquinoline, 1-acetylisoquinoline, and related compounds as inhibitors of herpes simplex virus in vitro and in a cutaneous herpes guinea pig model
}

\author{
Charles Shipman, Jr. ${ }^{1,2, *}$, Sandra H. Smith ${ }^{1, * *}$, John C. Drach ${ }^{1,3}$ and \\ Daniel L. Klayman ${ }^{4}$ \\ 'Department of Oral Biology, School of Dentistry, ${ }^{2}$ Department of Microbiology and Immunology, School \\ of Medicine, ${ }^{3}$ Interdepartmental Graduate Program in Medicinal Chemistry, The University of Michigan, \\ Ann Arbor, Michigan 48109, and 4 Division of Experimental Therapeutics, Walter Reed Army Institute of \\ Research, Washington, DC 20307, U.S.A.
}

(Received 23 July 1985; accepted 6 December 1985)

\section{Summary}

A series of 111 thiosemicarbazones of 2-acetylpyridine, 2-acetylquinoline, 1-acetylisoquinoline, and related compounds were evaluated as inhibitors of herpes simplex virus in vitro and in a cutaneous herpes guinea pig model. All derivatives tested were potent inhibitors of virus replication with mean $50 \%$ inhibitory concentrations of 1.1 $\mu \mathrm{g} / \mathrm{ml}$ for both type 1 and 2 herpes simplex virus. Inhibitory concentrations for cellular protein and DNA synthesis were considerably higher for many compounds resulting in in vitro therapeutic indices ranging from $>100$ (highly selective) to $<1$ (negatively selective).

All compounds were tested for dermal toxicity following topical administration of saturated solutions in 1,3-butanediol to the shaved, depilated skin of guinea pigs. Approximately $50 \%$ of the compounds produced slight to no dermal toxicity whereas the remaining compounds produced moderate to severe dermal toxicity.

28 compounds were evaluated in the cutaneous herpes guinea pig model against herpes simplex virus type 1 . A number of $N^{4}$-monosubstituted 2-acetylpyridine thio-

* Correspondence regarding this paper should be directed to Dr. Charles Shipman, Jr., The University of Michigan, School of Dentistry, Department of Oral Biology, Ann Arbor, MI 48109, U.S.A. Phone (313) 763-3331.

** Present address: Warner Lambert-Parke Davis, Pharmaceutical Research Division, Ann Arbor, MI 48105, U.S.A. 
semicarbazones produced highly significant reductions in days to healing and lesion score without producing untoward dermal toxicity.

Structure-activity relationships revealed that a reduction of the azomethine bond in the molecule (i.e., conversion of a thiosemicarbazone to a thiosemicarbazide) greatly diminished dermal toxicity apparently without producing a proportional decrease in antiviral activity.

thiosemicarbazones; antiviral compounds; herpes simplex virus; in vitro testing; guinea pig model; topical therapy

\section{Introduction}

The antiviral activity of thiosemicarbazones was reported first in 1950 by Hamre et al. [15] who found that derivatives of benzaldehyde thiosemicarbazone were active against neurovaccinial infection in mice when given orally. This prompted further investigation of other thiosemicarbazones. The thiosemicarbazone of isatin was found to be one of the most active [3], and a clinical trial of the $N$-methyl derivative of isatin- $\beta$-thiosemicarbazone (methisazone) was carried out in India [4-6]. The studies indicated that the drug was effective in the prevention of smallpox in persons exposed to the disease. Although these studies have been widely accepted as evidence of the effective antiviral activity of methisazone in humans, a subsequent field trial study demonstrated little efficacy [16]. The drug has been used also to treat patients with genital lesions caused by herpes simplex virus (HSV), but it had little effect on the severity or duration of the lesions [17].

Sidwell and co-workers evaluated a series of purine analogs as antiviral agents and demonstrated that purine-6-carboxaldehyde thiosemicarbazone was effective in suppressing both the cytopathic effect and the titers of human cytomegalovirus [27]. This was the first report of a substituted thiosemicarbazone being active against a herpesvirus. In addition, the effect of heterocyclic thiosemicarbazones was examined by Brockman and co-workers [7]. They tested the effect of several pyridine, isoquinoline, purine, and isatin derivatives on herpes simplex virus (HSV) and found that only those compounds in which the thiosemicarbazide moiety was affixed to the heterocyclic ring in the alpha position relative to the ring nitrogen were active. For example, the 2-formylpyridine derivative was active, whereas the 3-formylpyridine and 4-formylpyridine derivatives were inactive.

Thiosemicarbazones of 2-acetylpyridine have been found by Klayman et al. [18,19] to exhibit antimalarial activity in mice infected with Plasmodium berghei. Transition metal complexes of several 2-acetylpyridine thiosemicarbazones also have been prepared and tested for antimalarial properties [23].

Dobek and associates have reported [10,11] that many of the 2-acetylpyridine thiosemicarbazones described by Klayman et al. [18,19] were very active against Neisseria gonorrhoeae and $N$. meningitidis. Using a number of culturable mycobacteria in vitro, Collins and co-workers [9] have reported that significant activity was observed with a number of derivatives of 2-acetylpyridine thiosemicarbazone. 
We have been investigating the anti-herpesvirus activity of these thiosemicarbazones and have found that selected 2-acetylpyridine thiosemicarbazones inhibited the replication of herpes simplex virus types 1 and 2 (HSV-1 and HSV-2) to a greater extent than cellular DNA or protein synthesis [26]. The present communication extends these preliminary laboratory studies and presents additional data derived from a cutaneous herpes guinea pig model.

\section{Materials and Methods}

\section{In vitro studies}

The source of cells and HSV-1 (HF strain), the routine growth and passage of BHK-21/4 cells and $\mathrm{KB}$ cells, the propagation and titration of $\mathrm{HSV}$, the techniques used for the enumeration of cells, and the detection of mycoplasma contamination are described elsewhere [25]. HSV-2 (X79 strain) was kindly provided by Dr. Earle Kern (University of Utah).

The 2-acetylpyridine thiosemicarbazones were evaluated by means of a series of biochemical tests and virological assays previously described in detail [26]. In brief, the testing procedure consisted of examining the effects of candidate substances on titers of HSV-1 and HSV-2 undergoing replication and of conducting a battery of four biochemical tests to determine the effects of the candidate substances on cellular growth and metabolism as measures of cytotoxicity. The four biochemical tests were (i) $\left[{ }^{3} \mathrm{H}\right]$ amino acid incorporation into acid-precipitable material, (ii) $\left[{ }^{3} \mathrm{H}\right]$ thymidine incorporation into acid-precipitable material, (iii) DNA synthesis as measured by diphenylamine assays [8], and (iv) protein synthesis as measured by Lowry assays [20].

Dose-response relationships were constructed by linearly regressing log drug concentrations against the percent inhibition values derived for viral replication, incorporation of $\left[{ }^{3} \mathrm{H}\right]$ thymidine or $\left[{ }^{3} \mathrm{H}\right]$ amino acids, total protein, or total DNA. The $50 \%$ inhibitory concentrations were calculated from the regression lines by using methods previously described [12]. Samples containing arabinosyladenine (vidarabine, ara-A, provided through the courtesy of Dr. H.E. Machamer, Parke, Davis \& Co., Detroit, MI) at a concentration of $10 \mu \mathrm{g} / \mathrm{ml}$ were included in all assays as a positive control. Results from sets of assays were rejected whenever inhibition by ara-A deviated from its mean response by more than 1.5 standard deviations.

In order to be able to compare and rank compounds on the basis of their selective inhibition of viral replication versus cellular protein and DNA biosynthesis, an index we have called the 'in vitro therapeutic index' was derived. We define the index as the average $50 \%$ inhibitory concentration for cellular protein and DNA synthesis divided by the $50 \%$ inhibitory concentration for viral replication. Thus for the dimethyl derivative of 2-acetylpyridine thiosemicarbazone (compound 27), the in vitro therapeutic index for HSV-1 would be $[(2.0+2.1+0.24+1.8) / 4] / 0.08=19$. Similarly, dividing the resulting numerator by 0.17 would yield a value of 9 for HSV-2.

\section{Animal studies}

For the 5-day test of dermal toxicity, adult female guinea pigs weighing 300-400 $\mathrm{g}$ 
were shaved, depilated chemically, washed and dried. The hairless area was divided into six sections with a marking pen. Five areas were treated topically twice per day for 5 days with $0.7 \%$ solutions or suspensions of candidate compounds in 1,3-butanediol $(99+\%$, Aldrich Chemical Co., Milwaukee, WI). The sixth area received solvent only. Each compound was tested on two animals. Dermal toxicity was scored as none (0), very slight $( \pm)$, slight $(+)$, moderate $(++)$, or severe $(+++)$.

In the 14-day test for reduction of HSV-1 lesions, adult female guinea pigs weighing 300-400 g were shaved, depilated chemically, washed and dried under anesthesia (Innovar). The hairless area was divided into six squares with a marking pen. In the center of each area $25 \mu$ of strain S-148 HSV-1 (kindly supplied by Dr. Thomas Schafer, Schering Corporation, Bloomfield, NJ) at a titer of $3.2 \times 10^{6} \mathrm{PFU} / \mathrm{ml}$ was applied. The virus was inoculated under anesthesia with a spring-loaded vaccination instrument (Sterneedle Gun, Panray Division, Ormont Drug Co., Englewood, NJ), which was released 10 times producing inoculations $0.75 \mathrm{~mm}$ deep on each skin area. The procedure is essentially according to Schafer et al. [22] and Alenius and Öberg [1].

Three to four areas on each animal were treated topically twice per day for 5 days beginning $24 \mathrm{~h}$ after inoculation with $50 \mu \mathrm{l}$ of varying concentrations of candidate compounds as solutions or suspensions in 1,3-butanediol. One or two areas on each animal received solvent alone and served as the control site(s). One area was treated with either trisodium phosphonoformate (a gift of Dr. John Boezi, Michigan State University, East Lansing, MI) [2] or 2-acetylpyridine thiosemicarbazone (compound 1), compounds exhibiting known antiviral activity, as a positive control. When different substituted thiosemicarbazones were compared, one area on each animal was used for each substance. Seven parallel areas (seven animals) were used in most experiments. Any dermal toxicity due to the test compounds was noted.

To quantitate the effect of antiviral compounds, the scoring system of Alenius and Öberg [1] was used. After inoculation of the guinea pigs with HSV as described above, the inoculated areas were scored daily for 14 days. The animals were depilated every 3 or 4 days to facilitate observation. All scoring was done blind. Time to healing was noted also for each drug. A statistical program was developed to analyze the data using techniques of profile analysis, paired $t$-tests and analysis of variance.

Virus titers in infected skin were measured to confirm that the drugs inhibited viral replication and were not simply acting as anti-inflammatory agents. Guinea pigs were killed and the individual areas of inoculation sites excised. Skin samples were frozen and thawed once, minced with scissors, and homogenized (Tissumizer, Tekmar Co., Cincinnati, $\mathrm{OH}$ ) in ice-cold Hepes-buffered saline [24] ( $\mathrm{pH} 7.4)$ containing 100 units of penicillin and $100 \mu \mathrm{g}$ of streptomycin, respectively, per $\mathrm{ml}$. The suspensions were centrifuged at $1000 \times g$ and the centrifugate stored at $-76^{\circ} \mathrm{C}$ for subsequent assay in BHK-21/4 cells according to the procedure of Shipman et al. [25].

\section{Results}

\section{In vitro studies}

Tables 1 through 8 summarize the $50 \%$ inhibitory concentrations determined for 
111 related thiosemicarbazones. All derivatives tested (65 against HSV-1 and 15 against HSV-2) were potent inhibitors of virus replication with mean $50 \%$ inhibitory concentrations of $1.1 \pm 0.22$ (S.E.) $\mu \mathrm{g} / \mathrm{ml}$ for HSV-1 and $1.1 \pm 0.42 \mu \mathrm{g} / \mathrm{ml}$ for HSV-2 . When paired data for the 15 compounds tested against both types of herpes simplex virus were compared, the resulting means for HSV-1 and HSV-2 were $1.1 \pm 0.36 \mu \mathrm{g} / \mathrm{ml}$ and $1.1 \pm 0.42 \mu \mathrm{g} / \mathrm{ml}$, respectively. Some compounds $(27,30,46,51,68$, and 93$)$ were exceptionally potent inhibitors of viral replication with $50 \%$ inhibitory concentrations ranging from 40 to $90 \mathrm{ng} / \mathrm{ml}$.

Over 60 compounds were evaluated by both an isotopic and a nonisotopic method to determine $50 \%$ inhibitory concentrations for protein biosynthesis. There was good agreement between the two procedures with mean $50 \%$ inhibitory concentrations for uptake of [ ${ }^{3} \mathrm{H}$ ]amino acids of $20.0 \pm 10.2$ (S.E.) $\mu \mathrm{g} / \mathrm{ml}$ and $17.8 \pm 9.3 \mu \mathrm{g} / \mathrm{ml}$ for the Lowry method. Compounds varied widely in their capacity to inhibit protein synthesis. The two unsubstituted compounds, 2-acetylpyridine thiosemicarbazone (compound 1) and the semicarbazone analog (compound 106), had little effect on protein synthesis. Other compounds (see, for example, 53 and 68) with bulky substitutions at $N^{4}$ were potent inhibitors of protein synthesis.

Overall, the correlation between values derived for an isotopic and a nonisotopic method for measuring inhibition of DNA synthesis was satisfactory. Again, over 60 compounds were evaluated with resulting mean $50 \%$ inhibitory concentrations of 11.0 \pm 9.3 (S.E.) $\mu \mathrm{g} / \mathrm{ml}$ for the uptake of $\left[{ }^{3} \mathrm{H}\right]$ thymidine and $15.1 \pm 9.8 \mu \mathrm{g} / \mathrm{ml}$ for the diphenylamine assay. There were, however, several cases where inhibition of the uptake of $\left[{ }^{3} \mathrm{H}\right]$ thymidine was considerably greater than inhibition of DNA synthesis as measured by the nonisotopic method (see, for example, compounds 1, 2, 21, and 95). We have observed a similar disparity with the drug ribavirin and have determined that it was due to potent inhibition of the phosphorylation of $\left[{ }^{3} \mathrm{H}\right]$ thymidine rather than inhibition of DNA synthesis [13].

In vitro therapeutic indexes were computed for 56 compounds against HSV-1 and for 15 compounds against HSV-2. Values ranged from $\geqslant 100$ (highly selective) to $<1$ (negatively selective). For comparison, the in vitro therapeutic index of arabinosyladenine in this system is approximately 3 (data not shown). The inference that the compounds act more selectively against $\mathrm{HSV}-2$ must await confirmation with a larger number of compounds and additional strains of HSV-1 and HSV-2. In absolute numbers, three compounds $(1,2$, and 105$)$ produced in vitro therapeutic indexes of $\geqslant 100$ for both HSV-1 and HSV-2. Only the adamantyl derivative of 2-acetylpyridine thiosemicarbazone had an in vitro therapeutic index $>100$ for HSV-2 and $<100$ for HSV-1.

\section{Animal studies}

Saturated solutions (normally $0.7-1 \%$ ) in 1,3-butanediol of all compounds listed in Tables 1 through 8 were evaluated for dermal toxicity in guinea pigs. $20 \%$ of the compounds produced no dermal toxicity. Very slight toxicity (mild erythema in two or three animals out of seven) was seen in $14 \%$ of the compounds. Mild erythema was noted in another $14 \%$ of the test animals (one out of seven animals), while moderate and severe dermal toxicity was observed in 17 and $35 \%$ of compounds, respectively. In 


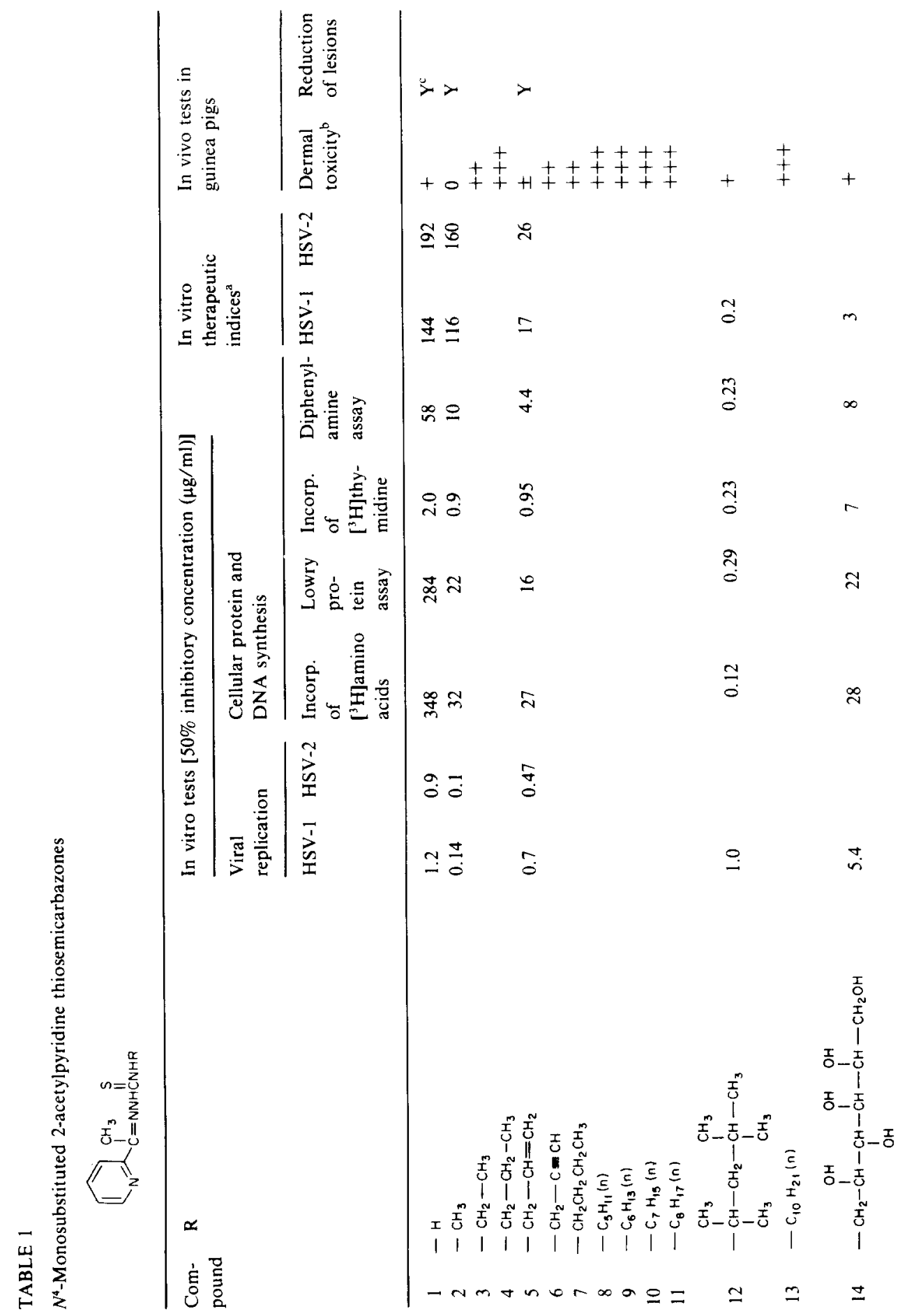




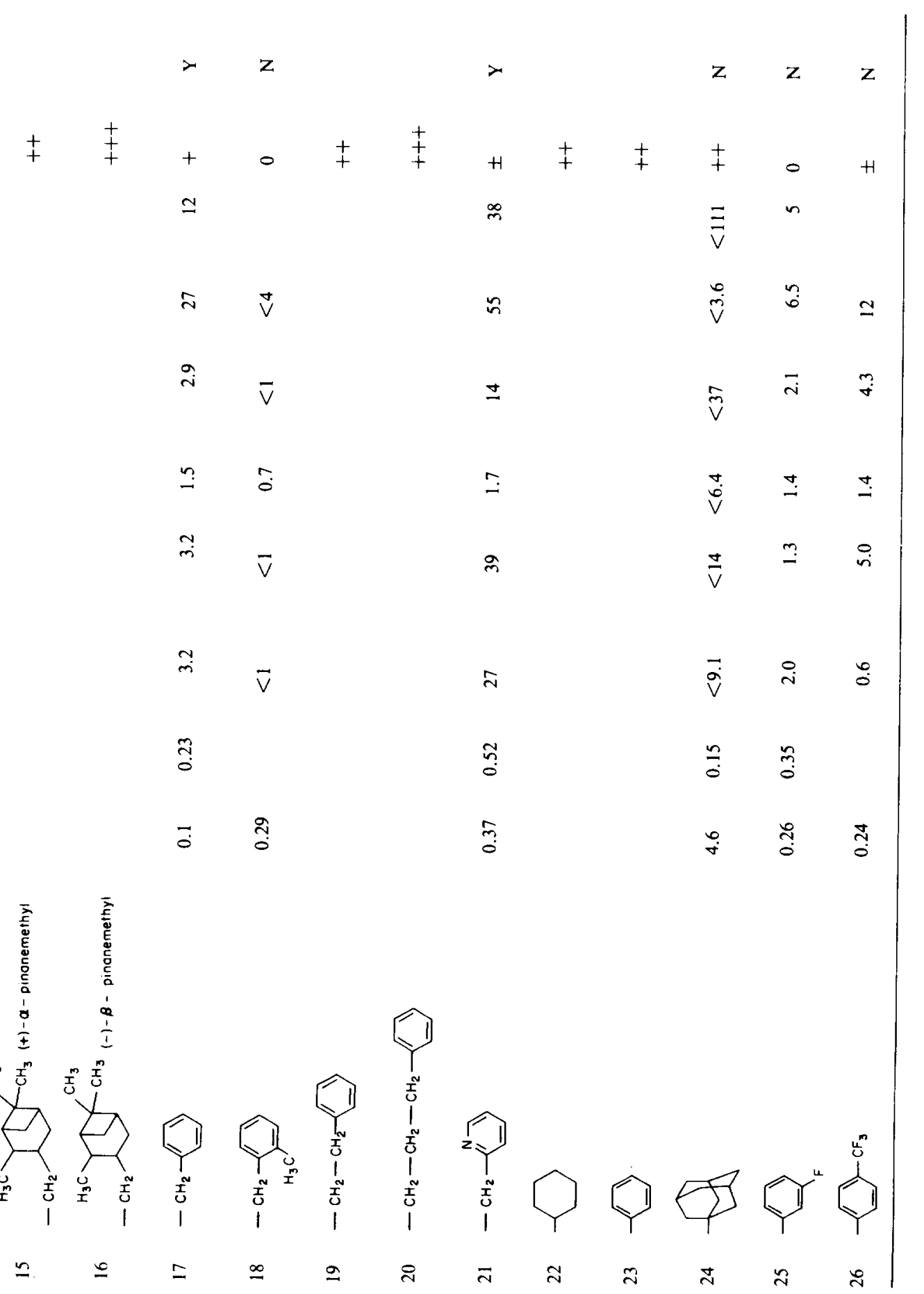




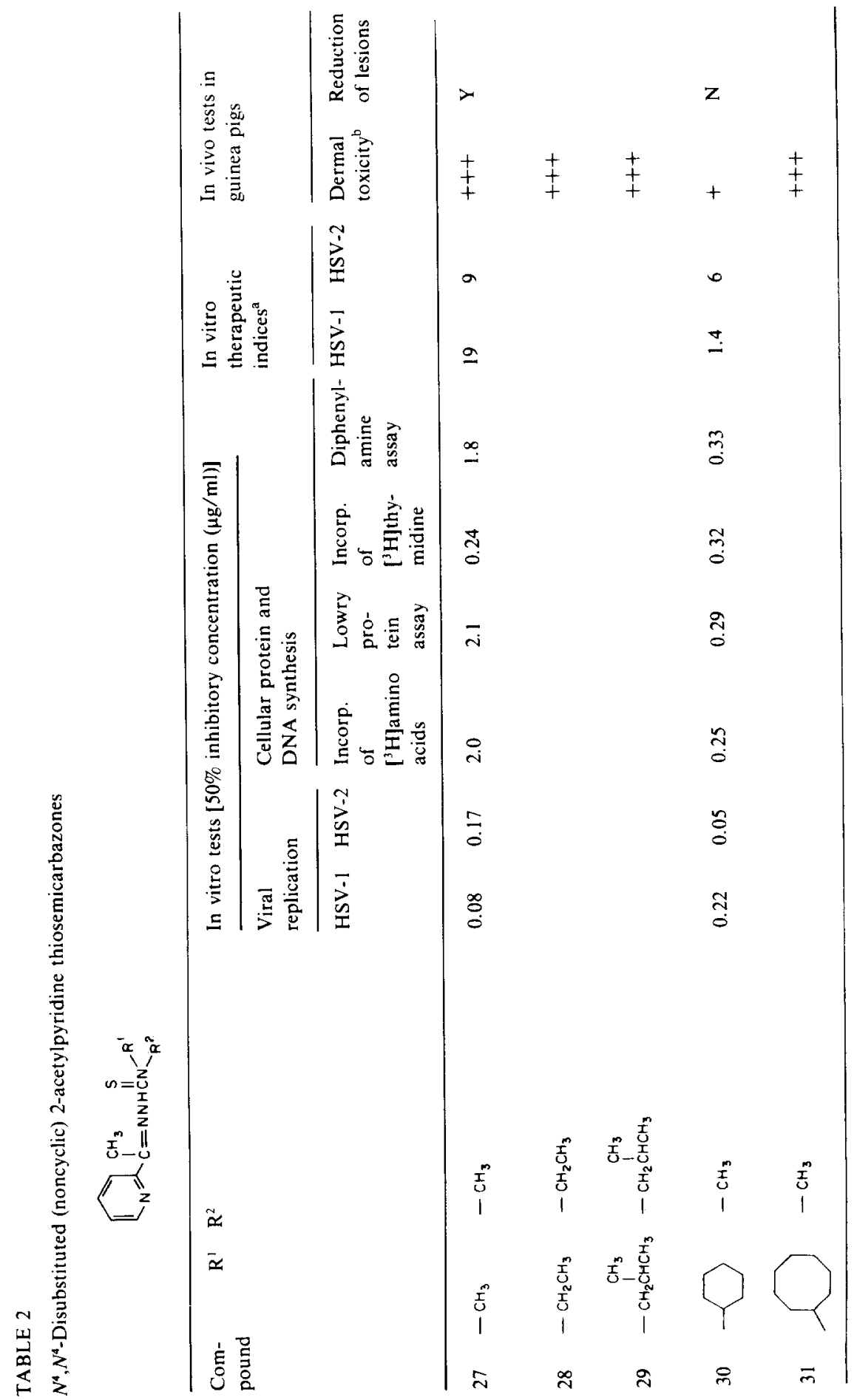




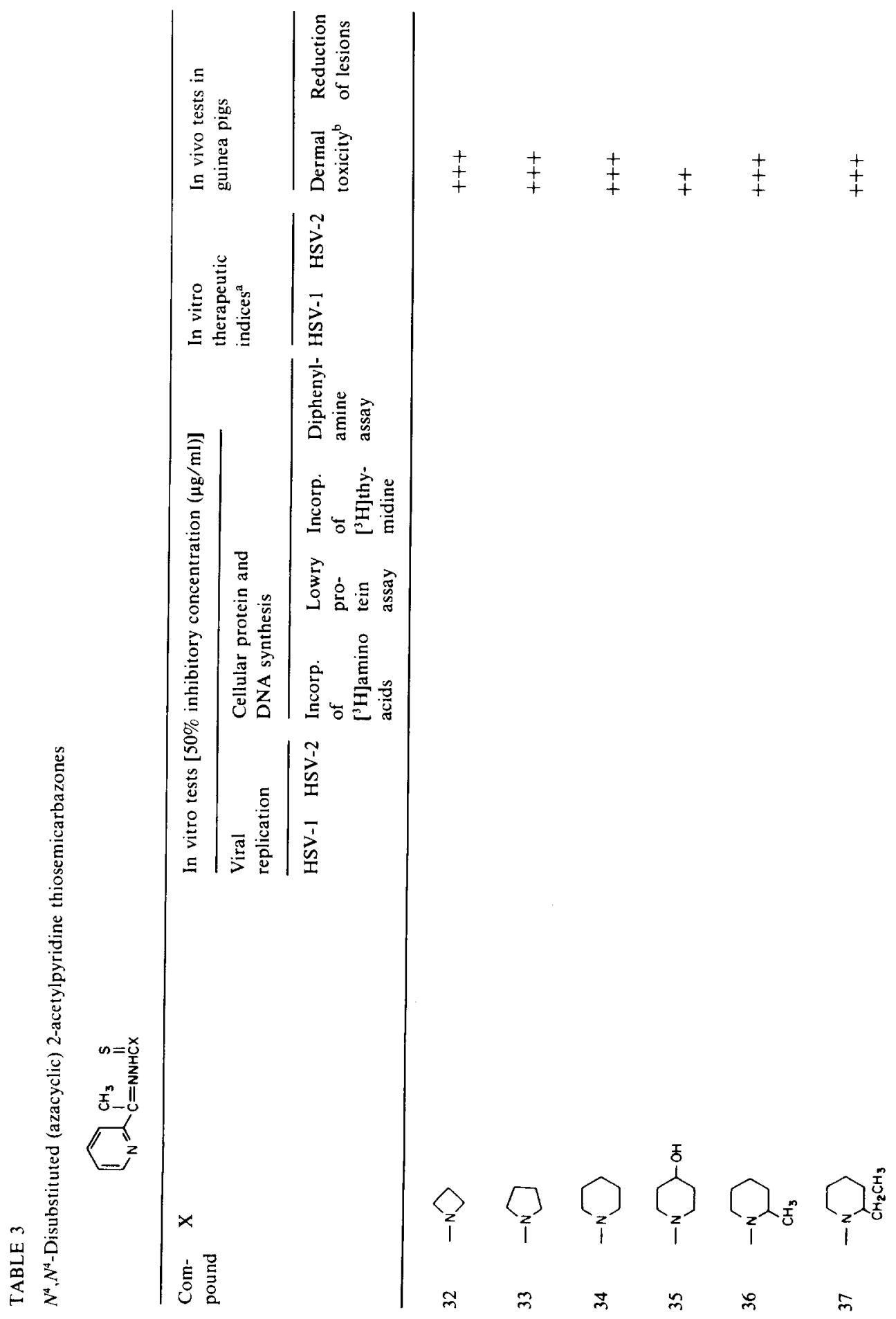




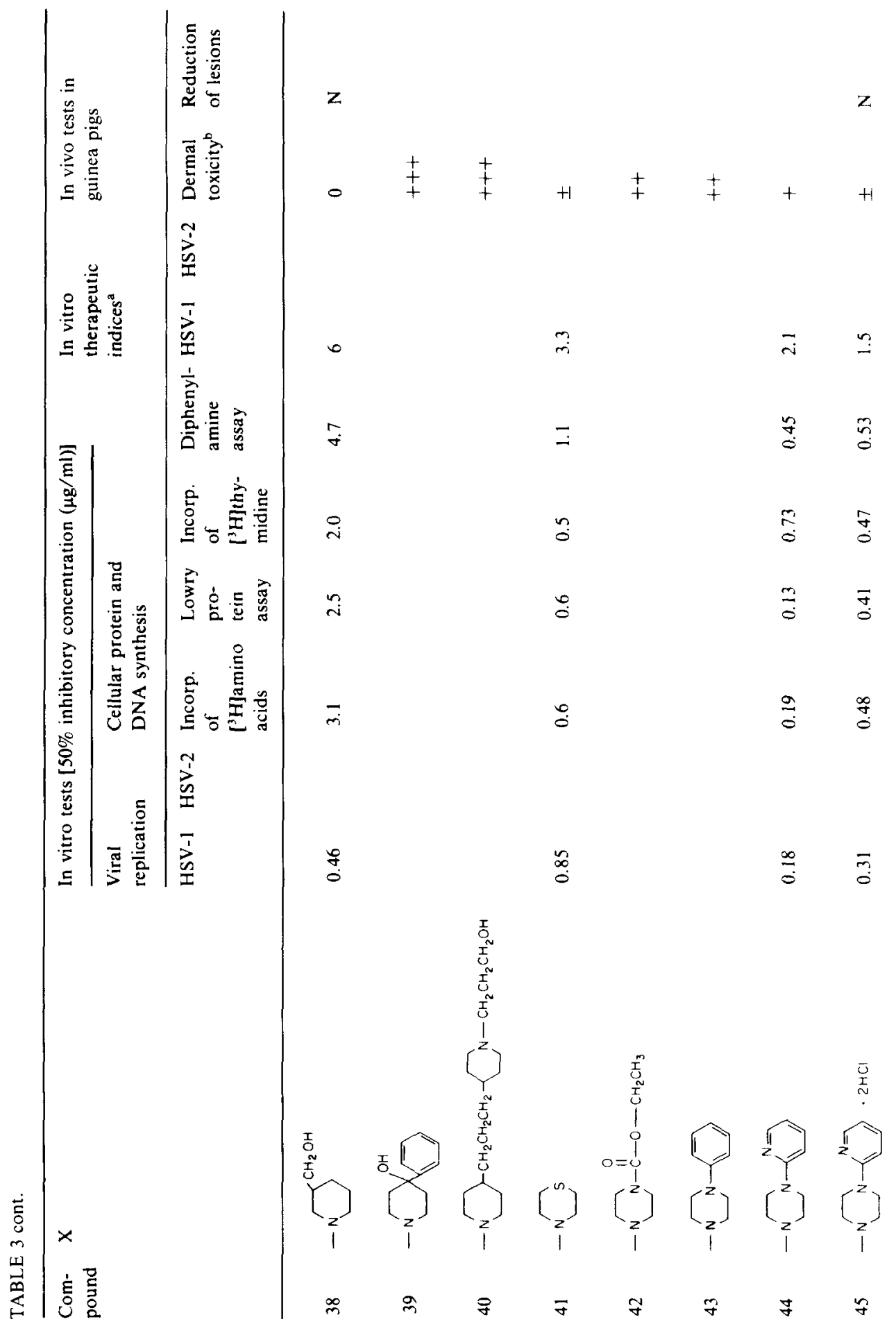




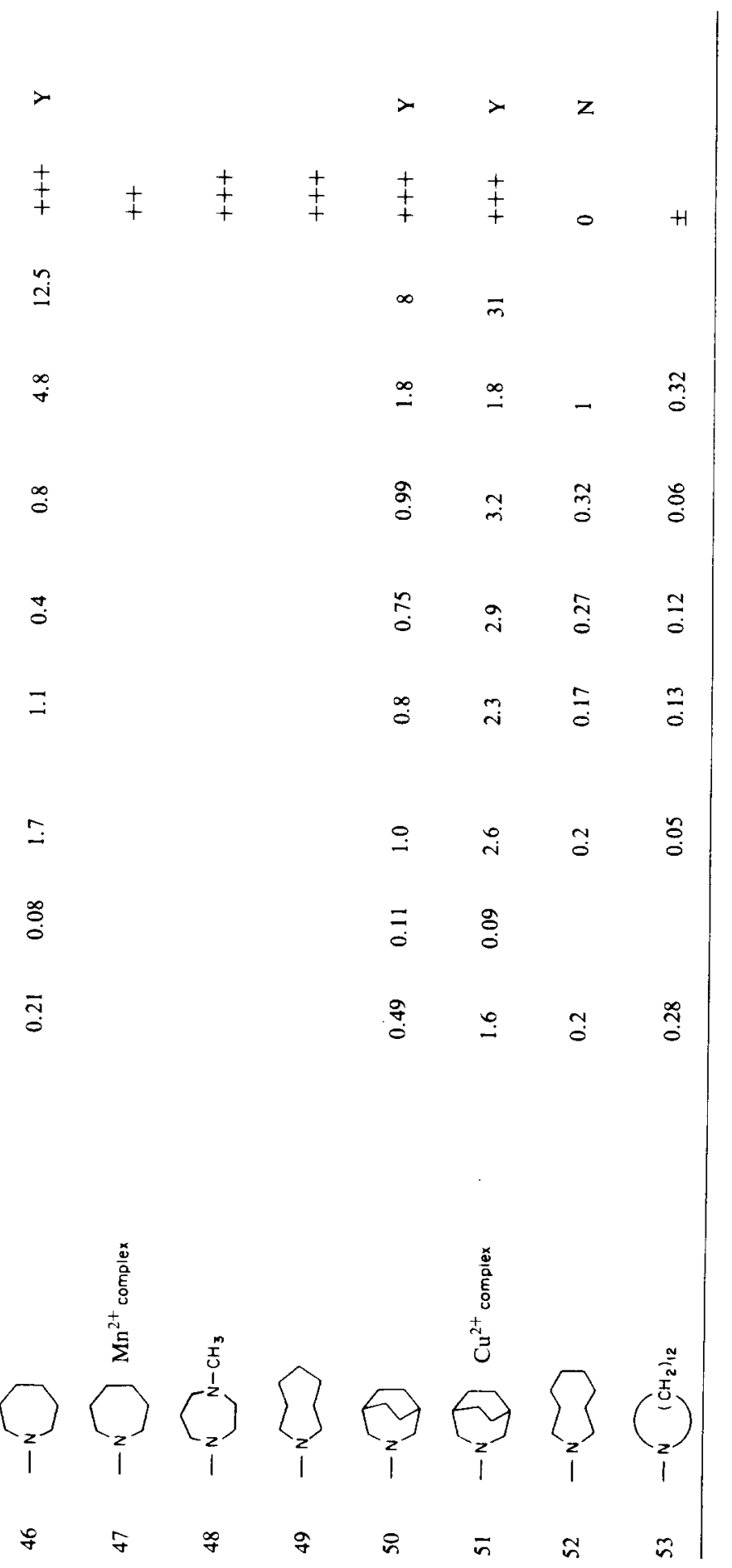




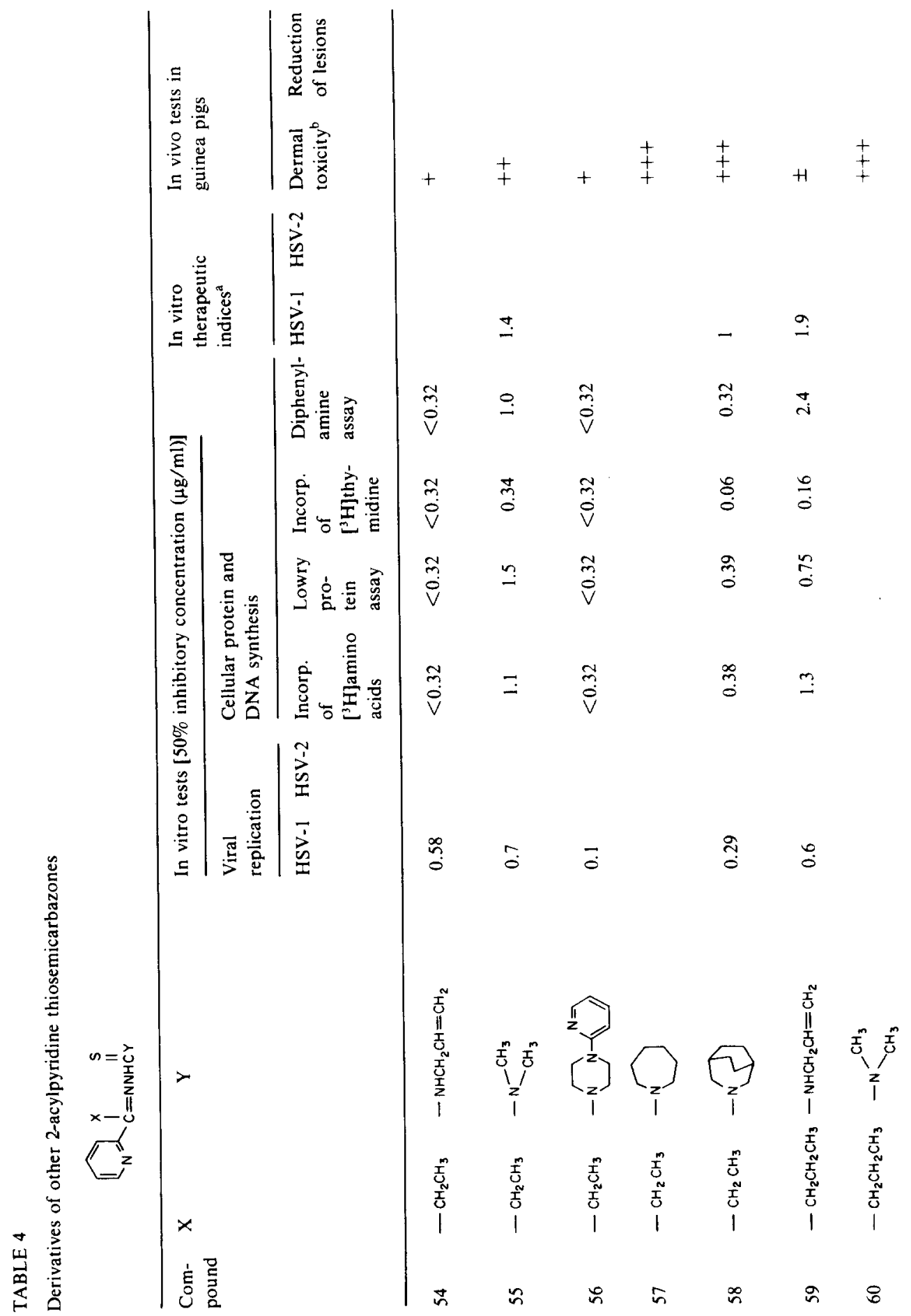




$$
\begin{aligned}
& \begin{array}{lll} 
& \\
z & z \\
0 & + & \\
+ & 0
\end{array} \\
& \stackrel{?}{-} \quad \stackrel{?}{-} \\
& \text { i } \quad \frac{0}{0} \quad \stackrel{\tilde{m}}{\circ}
\end{aligned}
$$

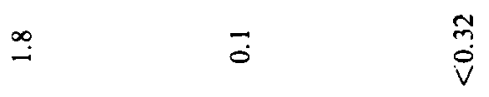

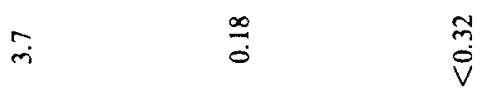

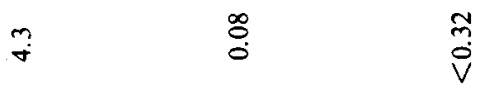

$$
\begin{aligned}
& \stackrel{0}{i} \quad \text { o } \\
& {\left[\begin{array}{l}
2 \\
2
\end{array}\right]}
\end{aligned}
$$

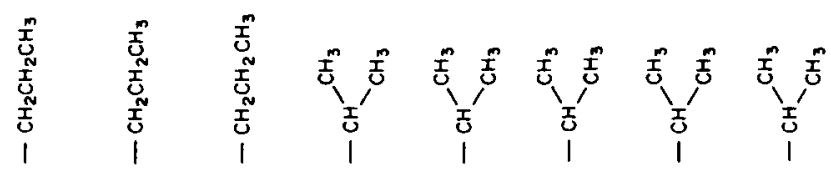

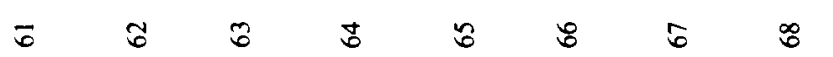




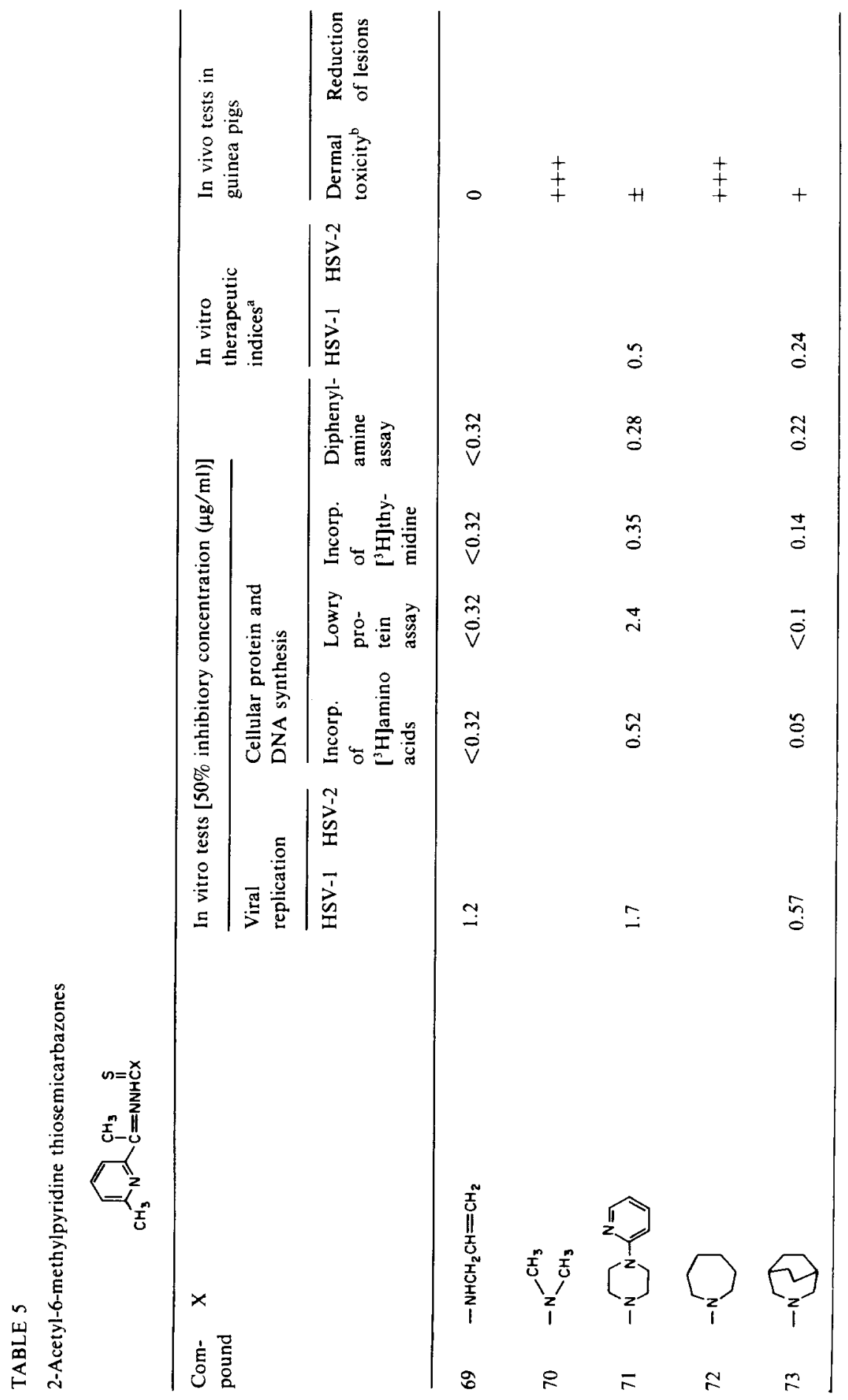


moderate and severe dermal toxicity, induration accompanied the erythema, and in severe dermal toxicity, desquamation followed. Further application of compound was stopped when severe dermal toxicity was observed.

28 compounds were evaluated in the cutaneous herpes guinea pig model. The usual criteria for selecting compounds for evaluation in this model were (i) an in vitro therapeutic index $>10$ and (ii) a score of,+ \pm , or 0 in the dermal toxicity test described in the above paragraph. The therapeutic effects of these compounds at various concentrations in 1,3-butanediol were compared after topical application on animals infected with HSV-1 (strain S-148). Treatment was initiated $24 \mathrm{~h}$ after inoculation. Fig. 1 illustrates the time course of the infection after application of placebo (1,3-butanediol), a saturated solution of compound $5(0.7 \%$, w/v $), 0.32 \%$ drug, $0.1 \%$ drug, and $0.032 \%$ drug. It is clear that although a $0.032 \%$ solution of this compound did not significantly reduce symptoms at any time during the infection, concentrations of $0.1 \%, 0.32 \%$, and $0.7 \%$ drug reduced total lesion score by $23 \%, 63 \%$, and $85 \%$, respectively. For comparison, $5 \%$ acyclovir in a polyethylene glycol base (Zovirax ${ }^{\circledR}$ ointment 5\%, Burroughs Wellcome Co., Research Triangle Park, NC) reduced total lesion score by $39 \%$ in this model (data not shown). Confirming results obtained in the dermal toxicity test using unabraded skin, compound 5 produced only a slight and transient dermal toxicity in some of the animals. Using similar procedures and analyses, 11 of the 28 compounds were shown to produce statistically significant reductions in lesion scores, whereas 17 of the 28 compounds tested were without effect.

Virus titers in the skin of placebo-treated and drug-treated animals were determined on day 4 following virus inoculation. Previous studies by others [22] and in our own laboratory (data not shown) have demonstrated that virus titers reach a peak on day 4 in both untreated and treated animals. For the determination of skin titers, four animals were killed 4 days after virus inoculation. Sections of the skin were aseptically

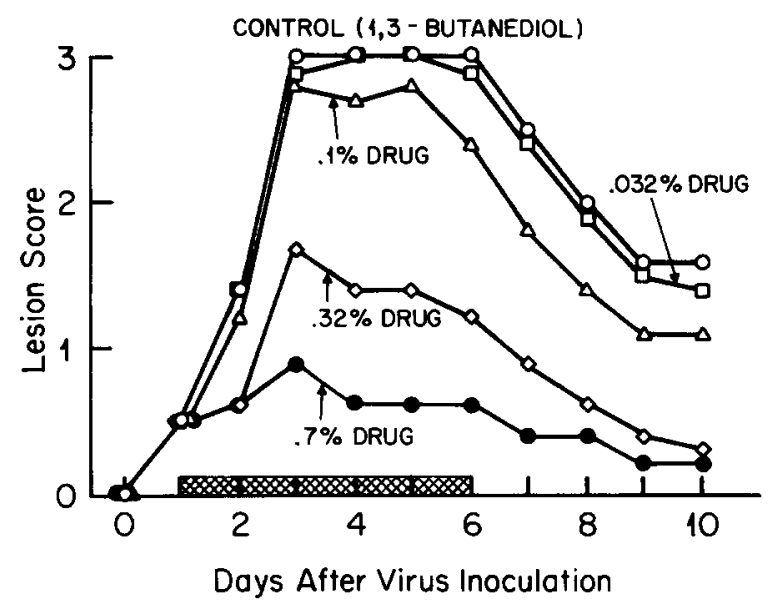

Fig. 1. Effect of 2-acetylpyridine 4-allyl-3-thiosemicarbazone (compound 5) on HSV-1 lesions in the cutaneous herpes guinea pig model. Treatment was started $24 \mathrm{~h}$ after inoculation and consisted of 2 daily applications of $50 \mu \mathrm{l}$ of drug for 5 days (see cross-hatched area). 


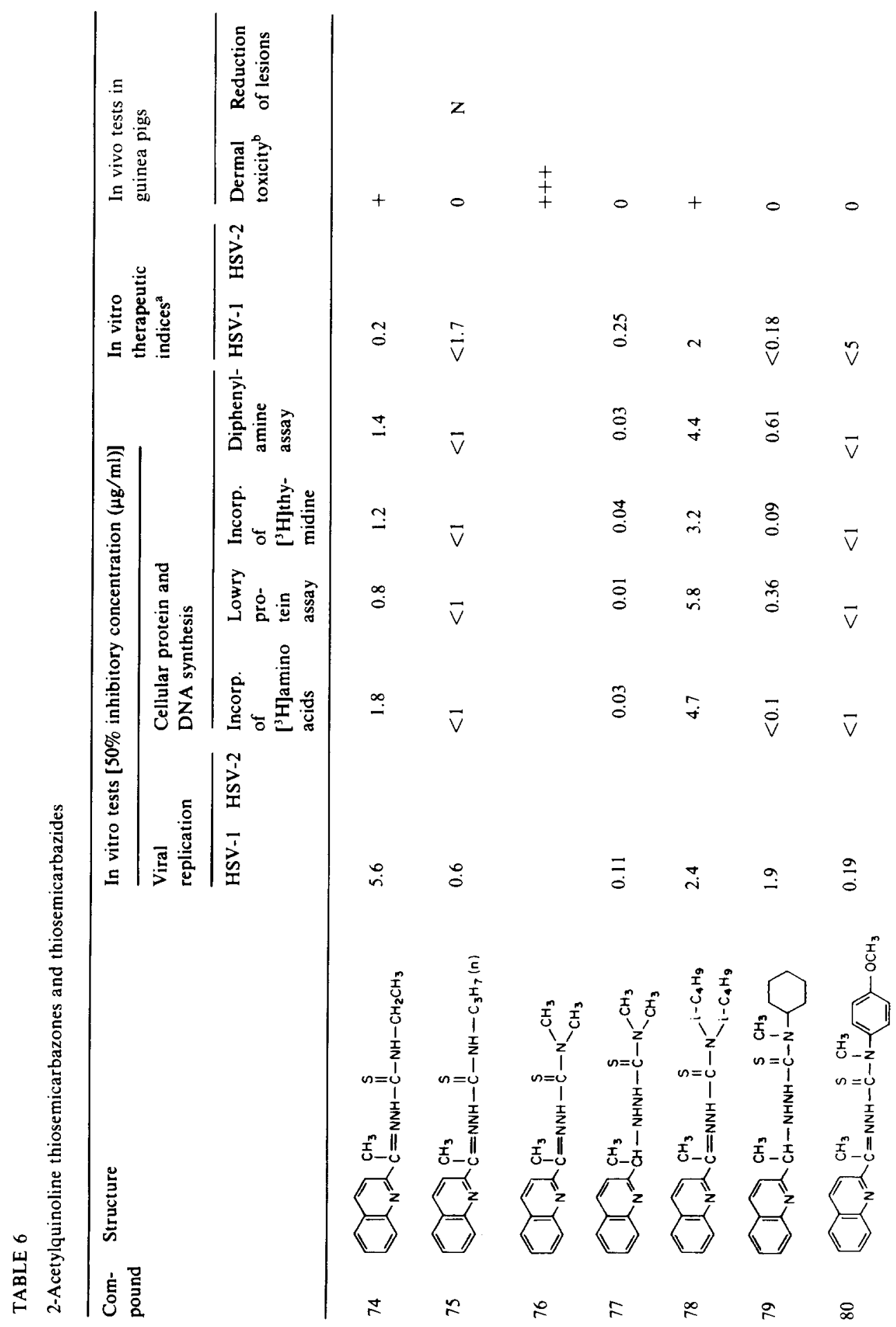




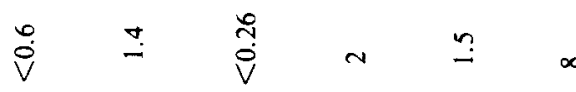

iv

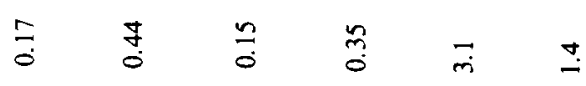

$\stackrel{\infty}{0}$

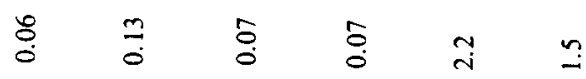

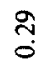

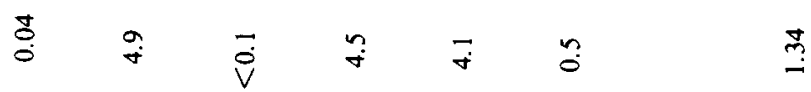

$\vec{i} \quad \vec{i} \quad \vec{\nabla} \quad \stackrel{0}{r} \quad \stackrel{m}{i}$

$\approx$

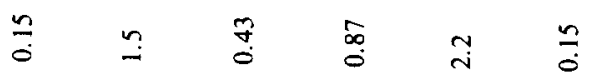

$\stackrel{m}{0}$

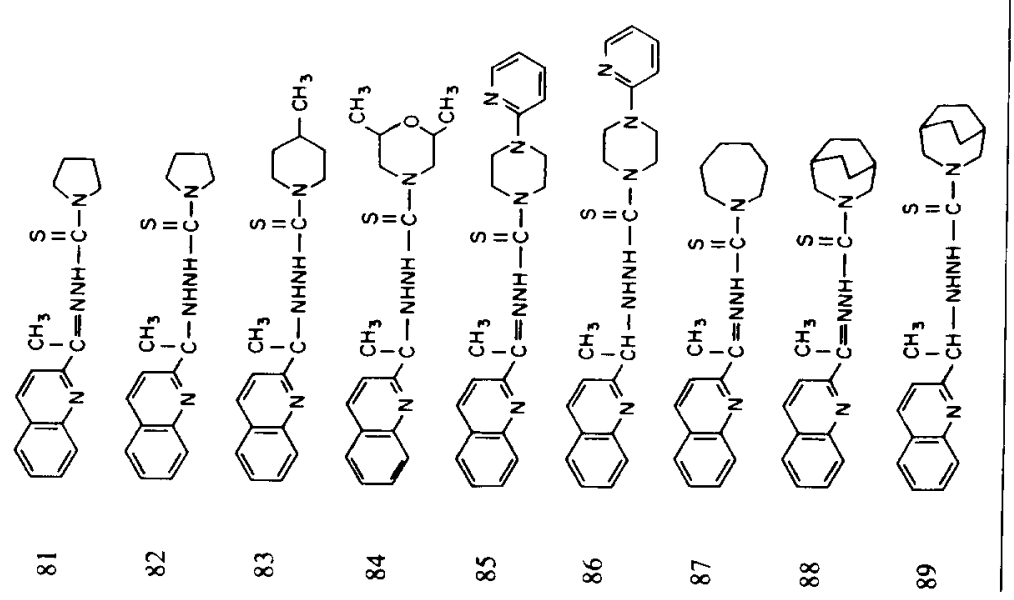




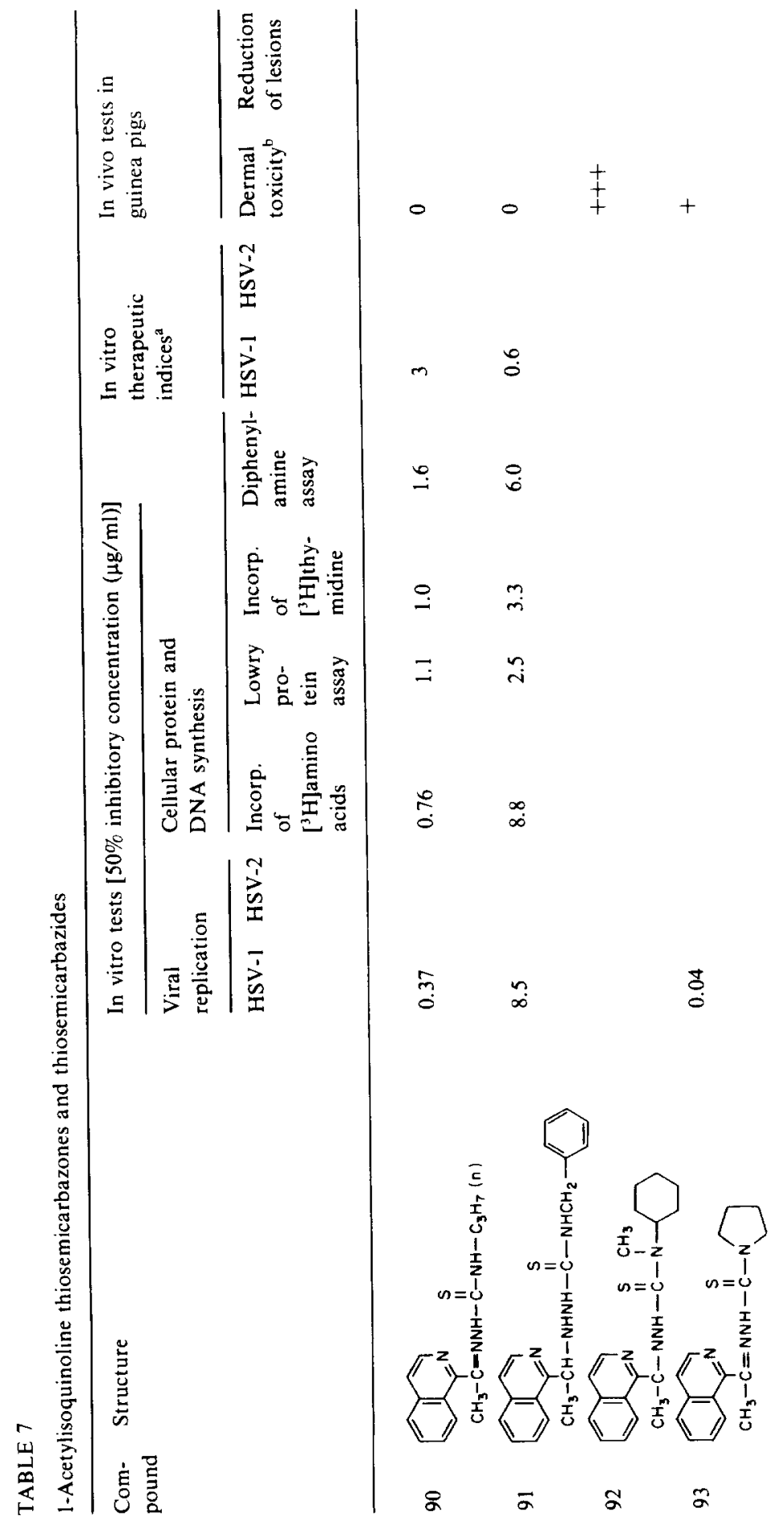




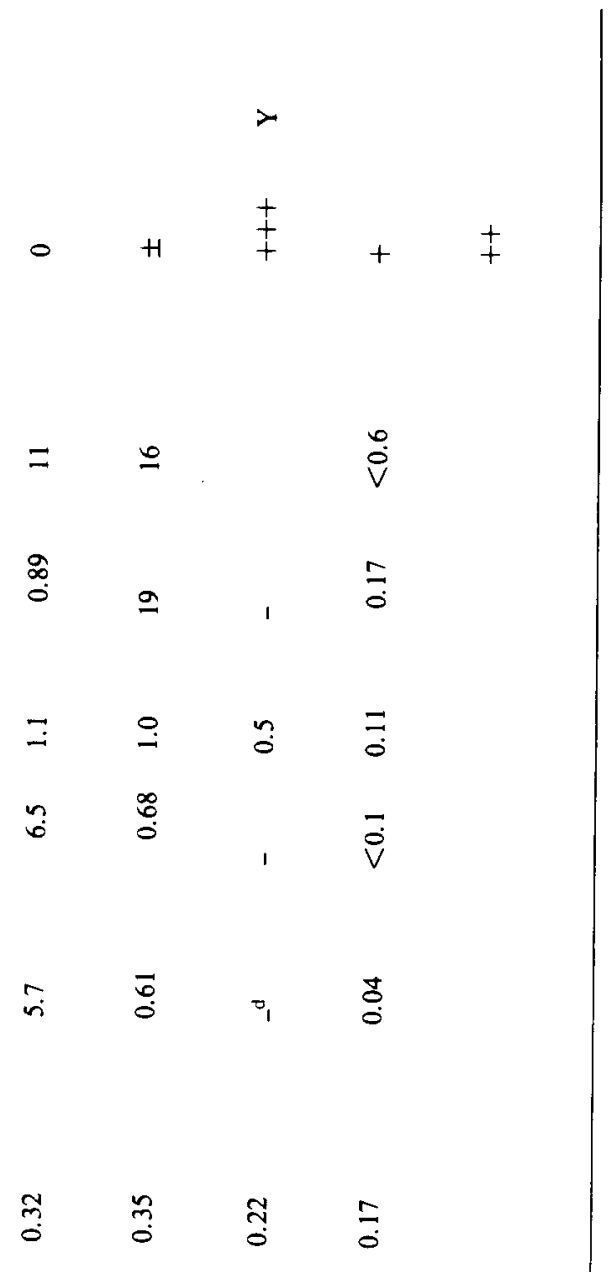

$$
\begin{aligned}
& \text { (1) }
\end{aligned}
$$

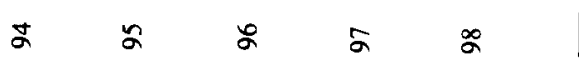




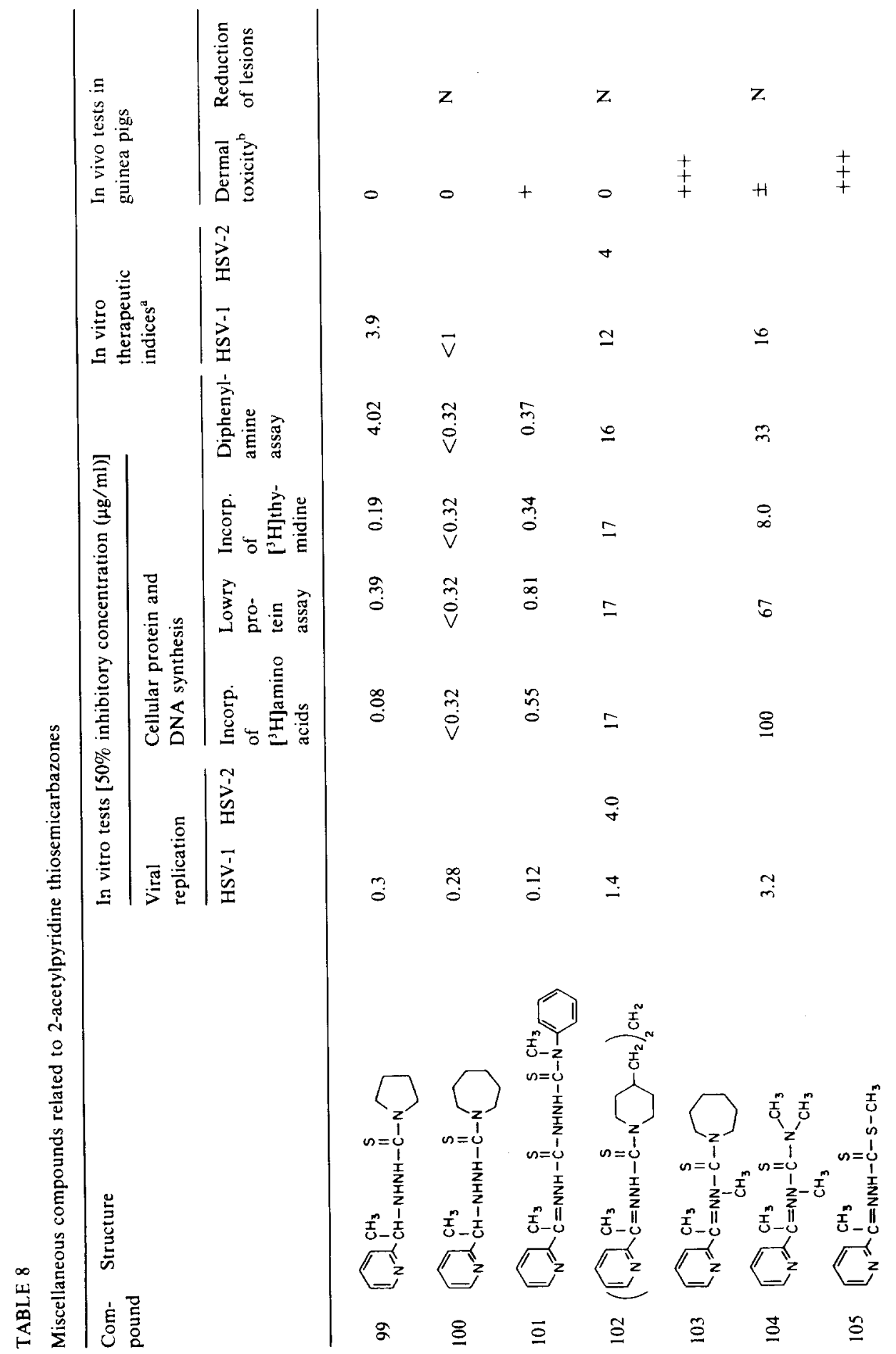




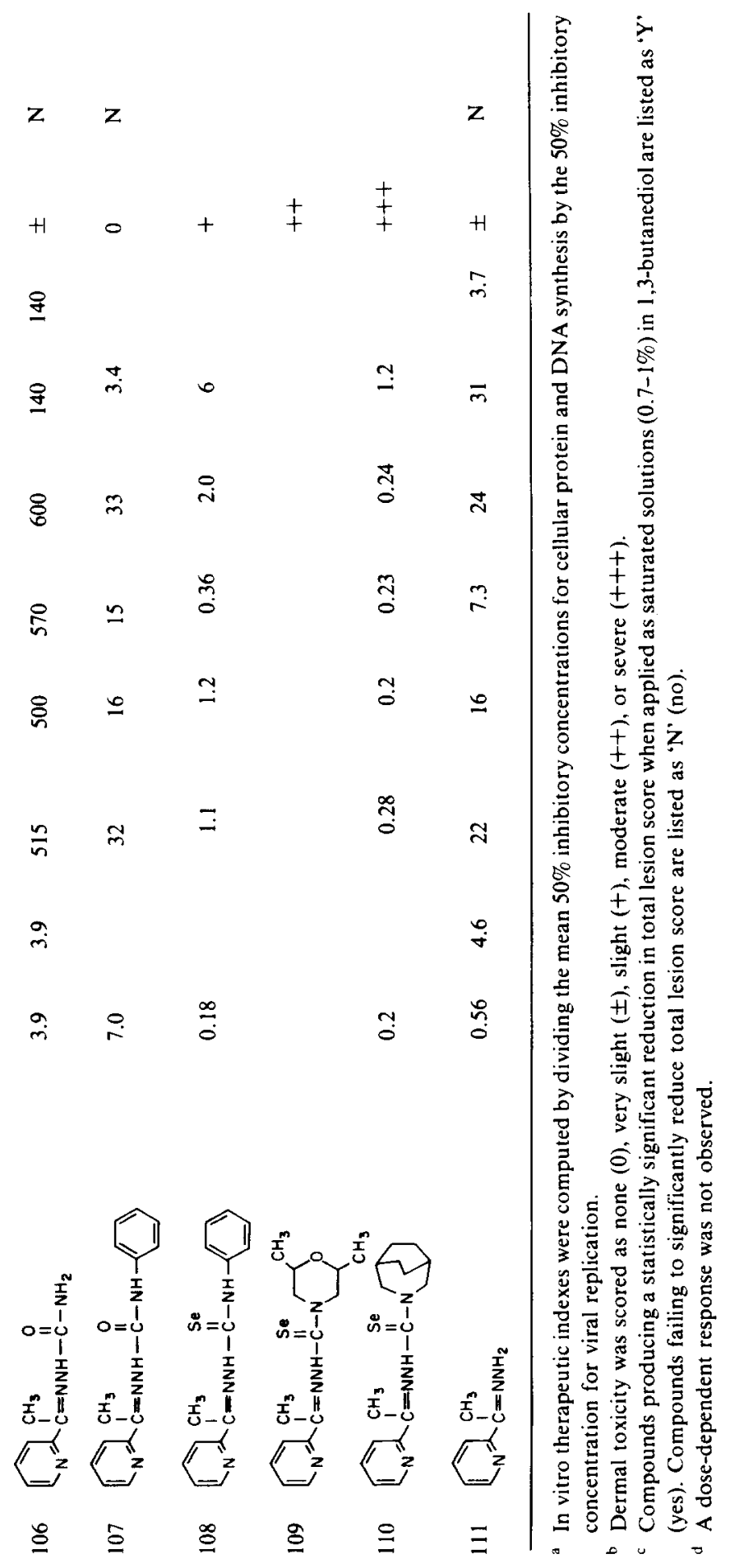


removed and processed as described in Materials and Methods (see above). Comparing vehicle alone with $1 \%$ compound 1 (a compound shown in separate experiments to be approximately as efficacious as compound 5 in the cutaneous herpes guinea pig model), the drug produced approximately a $70 \%$ reduction in virus titer (from a mean of $1.0 \times 10^{4} \mathrm{PFU} / \mathrm{ml}$ to $3.1 \times 10^{3} \mathrm{PFU} / \mathrm{ml}$ ). This difference, albeit not dramatic, was statistically highly significant $(\mathrm{P}=0.0001)$.

\section{Discussion}

The experiments presented here, which describe the potent inhibition of the replication of herpes simplex virus types 1 and 2 in both in vitro and in vivo situations by derivatives and compounds closely related to 2-acetylpyridine thiosemicarbazone, have been directed toward elucidating structure-activity relationships. For the purposes of this discussion, compounds will be considered as being $N^{4}$-monosubstituted 2-acetylpyridine thiosemicarbazones (class I), $N^{4}, N^{4}$-disubstituted (noncyclic) 2-acetylpyridine thiosemicarbazones (class II), $N^{4}, N^{4}$-disubstituted (azacyclic) 2-acetylpyridine thiosemicarbazones (class III), derivatives of other 2-acetylpyridine thiosemicarbazones (class IV), 2-acetyl-6-methylpyridine thiosemicarbazones (class V), 2-acetylquinoline thiosemicarbazones and thiosemicarbazides (class VI), 1-acetylquinoline thiosemicarbazones and thiosemicarbazides (class VII), and miscellaneous compounds related to 2-acetylpyridine thiosemicarbazones (class VIII). Each of these classes of compounds will be discussed, followed by a general discussion of all derivatives studied to date.

Class I compounds are the most promising of the derivatives studied to date. This class contains those chemicals with high in vitro therapeutic indexes, low dermal toxicity, and significant activity in the cutaneous herpes guinea pig model. The nine compounds in this class which were evaluated in the guinea pig model are listed in Table 9 together with their dermal toxicity scores, their in vitro therapeutic indexes and an indication of whether they produced a statistically significant reduction in total lesion score in the animal model. The compounds listed in this table are ranked in decreasing order of in vitro therapeutic indexes. There is a positive correlation between in vitro therapeutic index and activity in the cutaneous herpes guinea pig model; namely, in vitro therapeutic indexes $\geqslant 17$ correlate with activity in the animal model. Although it is tempting to ascribe this predictability to the validity of our biochemical screening method, in actuality we are quite unable to explain this phenomenon. As can be seen from a further examination of this table, there is neither a positive nor a negative correlation with dermal toxicity. The possibility that in vitro therapeutic index correlates with potency of the compounds in inhibiting viral replication and thus potent compounds are the only ones capable of efficacy in the guinea pig model can be rejected after examining Table 1.

In contrast to the monosubstituted compounds, $N^{4}, N^{4}$-disubstituted noncyclic compounds with one exception (compound 30 ) elicit severe dermal toxicity when tested on guinea pig skin. The dimethyl derivative (compound 27), with an in vitro therapeutic index of 19 against HSV-1, did produce a significant reduction of lesion score in the 


\section{TABLE 9}

A comparison of class I compounds evaluated in the cutaneous herpes guinea pig model

\begin{tabular}{llll}
\hline Compound No. & $\begin{array}{l}\text { In vitro } \\
\text { therapeutic } \\
\text { index }\end{array}$ & $\begin{array}{l}\text { Dermal } \\
\text { toxicity }\end{array}$ & $\begin{array}{l}\text { Reduction of } \\
\text { total lesion } \\
\text { score in } \\
\text { guinea pigs }\end{array}$ \\
\hline 1 & 144 & + & Yes \\
2 & 116 & 0 & Yes \\
21 & 55 & \pm & Yes \\
17 & 27 & + & Yes \\
5 & 17 & \pm & Yes \\
26 & 12 & \pm & No \\
25 & 6 & 0 & No \\
18 & $<4$ & 0 & No \\
24 & $<4$ & ++ & No \\
\hline
\end{tabular}

$a, b, c$ See footnotes to Tables $1-8$.

cutaneous herpes guinea pig model. Because of the severe dermal toxicity, however, this compound would not be suitable for chemotherapy. In a separate experiment (data not shown), guinea pigs were dosed with decreasing amounts of this compound in an attempt to find a concentration of cisug which would produce a significant antiviral effect without the concomitant dermal toxicity. Unfortunately, the highest concentration of drug not producing significant dermal toxicity was without significant antiviral activity.

Three of the class III compounds (46, 50, and 51) produced significant reductions of lesion scores in the cutaneous herpes guinea pig model. Again, however, these compounds produced a concomitant severe dermal toxicity and would not be suitable for chemotherapy.

Two 2-(2-methylpropionyl)pyridine thiosemicarbazone derivatives (class IV) were evaluated in the cutaneous herpes guinea pig model. Although both compounds (66 and 68 ) produced no dermal toxicity, neither compound showed any significant activity in the infected-animal model.

An examination of the 2-acetyl-6-methylpyridine thiosemicarbazone derivatives (class V) with their 2-acetylpyridine thiosemicarbazone counterparts (compare compounds 69 with 5, 71 with 44, and 73 with 50) suggests that the addition of the 6-methyl substituent increases the in vitro toxicity of these compounds. Indeed, the in vitro therapeutic indexes of the three compounds tested in this group are $\leqslant 0.5$ indicating that they are negatively selective when viewed as potential antiviral drugs.

Class VI and VII compounds, when considered collectively, exhibited relatively low in vitro therapeutic indexes and when active in the cutaneous herpes guinea pig model also produced moderate or severe dermal toxicity (compounds 87 and 96).

None of the compounds in class VIII were effective in inhibiting lesion formation in the infected guinea pig model. Compound 106, however, is of considerable interest. This compound, 2-acetylpyridine semicarbazone, is a relatively potent inhibitor of 
both HSV-1 and HSV-2 in vitro while producing little inhibition of cellular protein or DNA synthesis. A comparison of $50 \%$ inhibitory concentrations in the manner described previously in this communication yielded in vitro therapeutic indexes against HSV-1 and HSV-2 of 140, a value approximately equal to that obtained with 2 -acetylpyridine thiosemicarbazone. The semicarbazone produced very slight dermal toxicity in the guinea pig but was totally without curative effect in the cutaneous herpes guinea pig model. Although this structure-activity relationship is not understood, it may be that the semicarbazone is not transported across the skin whereas its thiosemicarbazone analog is.

Another interesting structure-activity relationship to be derived from a study of the 111 compounds is the observation that a reduction of the azomethine bond in the molecule (i.e., conversion of a thiosemicarbazone to a thiosemicarbazide) greatly diminishes dermal toxicity apparently without producing a proportional decrease in antiviral activity. Seven pairs of compounds were available for study where the only modification to the molecule was the reduction of the azomethine bond. These paired compounds are listed in Table 10 together with 50\% inhibitory concentrations for inhibition of HSV-1 and dermal toxicity scores. Considering a score of ' \pm ' to be equivalent to $1 / 2+$, the summed dermal toxicity score for the seven nonreduced compounds is 18+; this is in marked contrast to the summed dermal toxicity score of $1 \frac{1 / 2}{2}+$ for the seven reduced compounds. Viral replication data for three of the pairs (46-100,

TABLE 10

A comparison of paired thiosemicarbazones and thiosemicarbazides of 2-acetylpyridine and related compounds

\begin{tabular}{lll}
\hline Compound No. & Dermal toxicity & $\begin{array}{l}50 \% \text { Inhibitory concentrations } \\
\text { HSV }-1(\mu \mathrm{g} / \mathrm{ml})\end{array}$ \\
\hline 33 & $+++^{\mathrm{b}}$ & $\mathrm{NT}^{\mathrm{c}}$ \\
99 & 0 & 0.3 \\
46 & +++ & 0.21 \\
100 & 0 & 0.28 \\
76 & +++ & $\mathrm{NT}$ \\
77 & 0 & 0.11 \\
81 & +++ & $\mathrm{NT}$ \\
82 & 0 & 0.15 \\
85 & + & 0.87 \\
86 & \pm & 2.2 \\
88 & ++ & $\mathrm{NT}$ \\
89 & 0 & 0.33 \\
96 & +++ & 0.22 \\
97 & + & 0.17 \\
\hline
\end{tabular}

a Saturated solutions $(0.7-1.0 \%)$ of the test compound in 1,3-butanediol were applied twice per day for 5 days to the shaved and depilated backs of guinea pigs.

$b$ Scores: $0=$ no dermal toxicity; $\pm=$ very slight toxicity; $+=$ slight toxicity $++=$ moderate toxicity; +++ $=$ severe toxicity. See text for details.

c $\mathrm{NT}=$ Not tested. 
85-86, and 86-97) does not seem to indicate that reduction of the azomethine group has a significant effect on the antiviral activity of the compounds. Both compounds 46 and 100 have been tested in the cutaneous herpes guinea pig model. In this case, reduction of the azomethine bond appears to have eliminated in vivo antiviral activity.

Mechanism-of-action studies performed at The University of Michigan [28] strongly suggest that the potent antiviral activity of these compounds against herpes simplex virus type 1 is due to the selective inhibition of the virus-coded [14] ribonucleoside diphosphate reductase. This finding is in agreement with a report by Moore and Sartorelli that the cellular ribonucleotide reductase is inhibited by other closely related heterocyclic carboxaldehyde thiosemicarbazones [21].

From these data, it appears that there is potential clinical application for topical delivery of several 2-acetylpyridine thiosemicarbazones, especially those which are $N^{4}$-monosubstituted. Selected members of this group are potent inhibitors of herpes simplex virus in vitro, inhibit cellular functions to a lesser extent than viral functions, and are able to cross intact skin readily as evidenced by their efficacy in the cutaneous herpes guinea pig model.

\section{Acknowledgements}

We thank Professor Charles J. Kowalski for assistance with statistical analyses and Drs. John P. Scovill and Carl J. Mason for synthesizing the thiosemicarbazones described herein. This study was supported by a preliminary research grant from the Division of Research Development and Administration of The University of Michigan and medical research contract no. DAMD 17-81-C-1128 from the United States Army Medical Research and Development Command.

The views, opinions, and/or findings of the research do not necessarily reflect the position, or decision of the United States Army and no official endorsement should be inferred.

\section{References}

1 Alenius S. and Öberg, B. (1978) Comparison of the therapeutic effects of five antiviral agents on cutaneous herpesvirus infection in guinea pigs. Arch. Virol. 58, 277-288.

2 Alenius, S., Dinter, Z. and Öberg, B. (1978) Therapeutic effect of trisodium phosphonoformate on cutaneous herpesvirus infection in guinea pigs. Antimicrob. Agents Chemother. 14, 408-413.

3 Bauer, D.J. (1955) The antiviral synergic actions of isatin thiosemicarbazone and certain phenoxypyrimidines in vaccinia infection in mice. Br. J. Exp. Pathol. 36, 105-114.

4 Bauer, D.J. (1965) Clinical experience with the anti-viral drug Marboran (1-methylisatin 3-thiosemicarbazone). Ann. N.Y. Acad. Sci. 130, 110-117.

5 Bauer, D.J., St. Vincent, L., Kempe, C.H. and Downie, A.W. (1963) Prophylactic treatment of smallpox contacts with $\mathrm{N}$-methylisatin $\beta$-thiosemicarbazone. Lancet ii, 494-496.

6 Bauer, D.J., St. Vincent, L., Kempe, C.H., Young, P.A. and Downie, A.W. (1969) Prophylaxis of smallpox with methisazone. Am. J. Epidemiol. 90, 130-145.

7 Brockman, R.W., Sidwell, R.W., Arnett, G. and Shaddix, S. (1970) Heterocyclic thiosemicarbazones: correlation between structure, inhibition of ribonucleotide reductase, and inhibition of DNA viruses. Proc. Soc. Exp. Biol. Med. 133, 609-614. 
8 Burton, K. (1968) Determination of DNA concentration with diphenylamine. Methods Enzymol. 12, 163-166.

9 Collins, F.M., Klayman, D.L. and Morrison, N.E. (1982) Correlations between structure and antimycobacterial activity in a series of 2-acetylpyridine thiosemicarbazones. J. Gen. Microbiol. 128, 1349-1356.

10 Dobek, A.S., Klayman, D.L., Dickson, E.T., Jr., Scovill, J.P. and Tramont, E.C. (1980) Inhibition of clinically significant bacterial organisms in vitro by 2-acetylpyridine thiosemicarbazones. Antimicrob. Agents Chemother. 18, 27-36.

11 Dobek, A.S., Klayman, D.L., Dickson, E.T., Jr., Scovill, J.P. and Oster, C.N. (1983) Thiosemicarbazones of 2-acetylpyridine, 2-acetylquinoline, 1- and 3-acetylisoquinoline and related compounds as inhibitors of clinically significant bacteria in vitro. Arzneim.-Forsch. (Drug Res.) 33, 1583-1591.

12 Drach, J.C. and Shipman, C., Jr. (1977) The selective inhibition of viral DNA synthesis by chemotherapeutic agents: an indicator of clinical usefulness? Ann. N.Y. Acad. Sci. 284, 396-406.

13 Drach, J.C., Thomas, M.A., Barnett, J.W., Smith, S.H. and Shipman, C., Jr. (1981) Tritiated thymidine incorporation does not measure DNA synthesis in ribavirin-treated human cells. Science 212, 549-551.

14 Dutia, B.M. (1983) Ribonucleotide reductase induced by herpes simplex virus has a virus-specified constituent. J, Gen. Virol. 64, 513-521.

15 Hamre, D., Bernstein, J. and Donovick, R, (1950) Activity of $p$-aminobenzaldehyde 3-thiosemicarbazone on vaccinia virus in the chick embryo and in the mouse. Proc. Soc. Exp. Biol. Med. 73, 275-278.

16 Heiner, G.G., Fatima, N., Russell, P.K., Haase, A.T., Ahmad, N., Mohammed, N., Thomas, D.B., Mack, T.M., Khan, M.M., Knatterud, G.L., Anthony, R.L. and McCrumb, F.R., Jr. (1971) Field trials of methisazone as a prophylactic agent against smallpox. Am. J. Epidemiol. 94, 435-449.

17 Hutfield, D.C. and Csonka, G.W. (1964) Marboran in herpes genitalis. Lancet i, 329-330.

18 Klayman, D.L., Bartosevich, J.F., Griffin, T.S., Mason, C.J. and Scovill, J.P. (1979) 2-Acetylpyridine thiosemicarbazones. I. A new class of potential antimalarial agents. J. Med. Chem. 22, 855-862.

19 Klayman, D.L., Scovill, J.P., Bartosevich, J.F. and Mason, C.J. (1979) 2-Acetylpyridine thiosemicarbazones. 2. $N^{4}, N^{4}$-disubstituted derivatives as potential antimalarial agents. J. Med. Chem. 22 , 1367-1373.

20 Lowry, O.H., Rosebrough, N.J., Farr, A.L. and Randall, R.J. (1951) Protein measurement with the Folin phenol reagent. J. Biol. Chem. 193, 265-275.

21 Moore, E.C. and Sartorelli, A.C. (1984) Inhibition of ribonucleotide reductase by $\alpha-(N)$-heterocyclic carboxaldehyde thiosemicarbazones. Pharmacol. Ther. 24, 439-447.

22 Schafer, T.W., Lieberman, M., Everitt, J. and Came, P. (1977) Cutaneous herpes simplex virus infection of guinea pigs as a model for antiviral chemotherapy. Ann. N.Y. Acad. Sci. 284, 624-631.

23 Scovill, J.P., Klayman, D.L. and Franchino, C.F. (1982) 2-Acetylpyridine thiosemicarbazones. 4. Complexes with transition metals as antimalarial and antileukemic agents. J. Med. Chem. 25, $1261-1264$.

24 Shipman, C., Jr. (1969) Evaluation of 4-(2-hydroxyethyl)-1-piperazineethanesulfonic acid (HEPES) as a tissue culture buffer. Proc. Soc. Exp. Biol. Med. 130, 305-310.

25 Shipman, C., Jr., Smith, S.H., Carlson, R.H. and Drach, J.C. (1976) Antiviral activity of arabinosyladenine and arabinosylhypoxanthine in herpes simplex virus-infected KB cells: selective inhibition of viral deoxyribonucleic acid synthesis in synchronized suspension cultures. Antimicrob. Agents Chemother. 9, 120-127.

26 Shipman, C., Jr., Smith, S.H., Drach, J.C. and Klayman, D.L. (1981) Antiviral activity of 2-acetylpyridine thiosemicarbazones against herpes simplex virus. Antimicrob. Agents Chemother. 19, 682-685.

27 Sidwell, R.W., Arnett, G., Dixon, G.J. and Schabel, F.M., Jr. (1969) Purine analogs as potential anticytomegalovirus agents. Proc. Soc. Exp. Biol. Med. 131, 1223-1230.

28 Turk, S.R., Drach, J.C. and Shipman, C., Jr. (1986) Selective inhibition of herpes simplex virus ribonucleoside diphosphate reductase by derivatives of 2-acetylpyridine thiosemicarbazone. Biochem. Pharmacol., in press. 